\title{
Trump Country
}

Af Sten Rynning \& Christilla Roederer-Rynning

The talk of the town her i Washington DC har været, om præsidentem vil holde i alle fire år, som han er valgt til. Det er et spørgsmål, som selvsagt kun opstår, fordi Trump som ny nationalistisk bannerfører skaber stor ængstelse. Men vi kan lige så godt vænne os til ham, for han sidder sine fire år ud. Det er muligt, at eksplosive afsløringer i sagen om forholdet mellem Trump og Rusland dukker op, og så er alt muligt. Men i fraværet heraf, så har vi godt og vel fire år til at forstå, hvorfor amerikansk nationalisme har fået vind i sejlene, og hvad Trump kan bruge det til.

Helt i tråd med nationalismens logik appellerer Trump til 'folket' - nationen - og ikke mindst nationens marginaliserede, som skal have deres job og stolthed tilbage.

Trump er nationalistisk og i modsætning til USA's rolle som leder af en international orden. Hvad der nu vil ske, er et godt spørgsmål. Måske vil Trump rykke grundlaget for Vesten væk, og den liberale orden vil falde. Men det er ikke sik- kert, at Trump vil udleve den rene og i sidste ende destruktive nationalisme. Og det er slet ikke sikkert, at han kan, for det er komplekst at styre et land som USA, og det internationale samfund har også en stemme.

\section{Trumps mærkværdige hold}

Vi begynder artiklen med en status på Trumps hold i Washington. Det er broget og vidner om en præsident, som ikke kan bero sig på sin evne til at lave vanlige politiske løsninger. Der må være en anden kilde til energi. Denne vender vi os mod i andet afsnit, hvor vi ser på populisme i amerikansk politik og historie. Dernæst vender vi os mod to arenaer, hvor Trump skal balancere energi og holdspil for at skabe forandring - dels i Nordamerika, dels bredere internationalt. Konklusionen er, at Trump vil få det svært og vil falde tilbage på sine populistiske, symbolske dyder. Han vil blive 'the campaigning president', og formentlig vil han efter fire år erklære sin sejr og undlade at stille op til genvalg.

Noget af det mest slående ved at følge

Sten Rynning, professor, og Christilla Roederer-Rynning, lektor, Syddansk Universitet, er i foråret 2017 på forskningsophold på American University, Washington DC. Sten Rynning takker de fonde, som har finansieret hans forskningsophold i USA: Fulbright Commission, Forskningsrådet for Samfund og Erhverv, Ragna Rask-Nielsen Grundforskningsfond og Torben og Alice Frimodts Fond. 


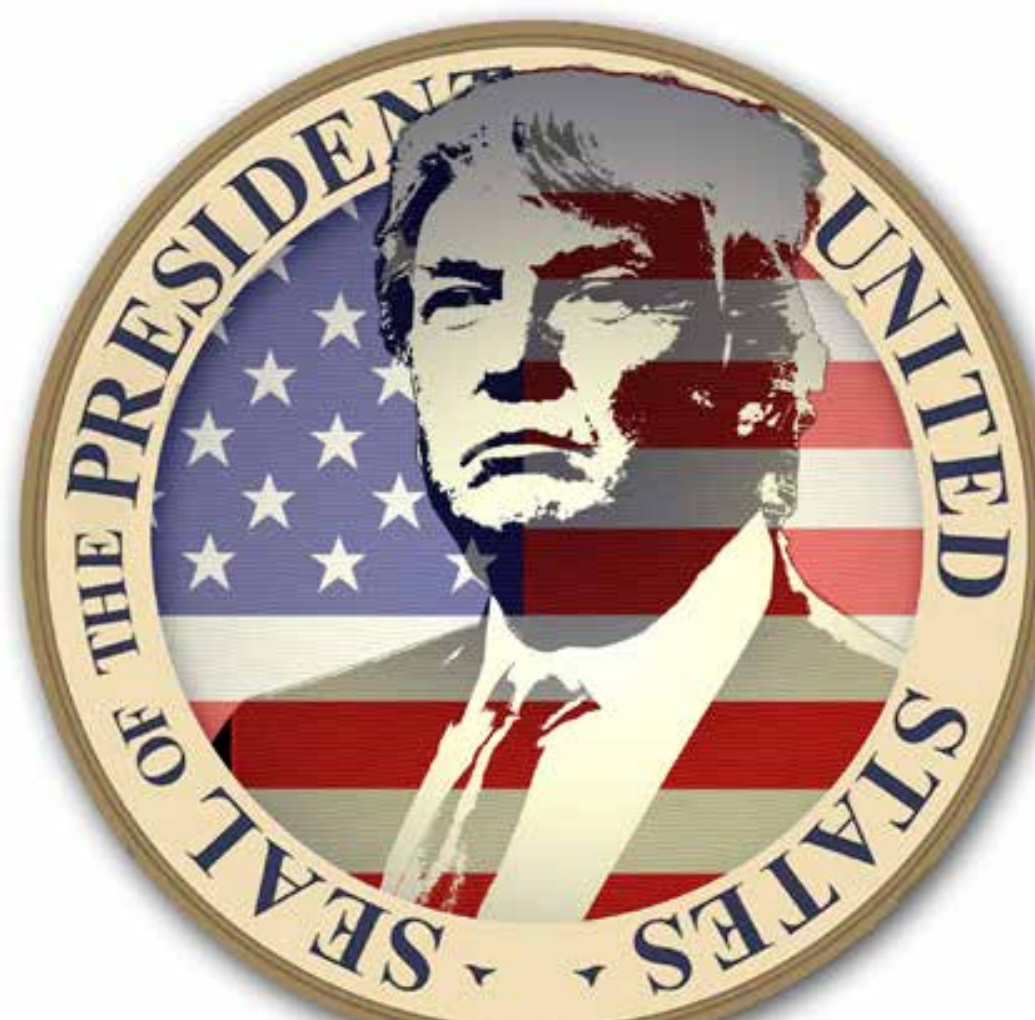

FOTO: Chris Van Es/Newsart

Donald Trump 


\section{Trump vil få det svært og vil falde tilbage på sine populistiske, symbolske dy- der. Han vil blive 'the campaigning president', og formentlig vil han efter fire år erklære sin sejr og undlade at stille op til genvalg.}

Donald Trump som præsident - hvilket i skrivende stund har varet ved i 55 dage er hans næsten komplette mangel på politisk base og erfaring. Med politisk base skal der ikke forstås de mennesker, der stemte på ham, men derimod et netværk af politiske kræfter, der kan træde ind og hjælpe ham med at regere. Det forklarer, hvorfor Trumps administration er så tyndt besat i toppen; hvorfor det Hvide Hus er dybt splittet; og hvorfor Trump har det med at vende sig mod en gruppe mennesker, som typisk er republikansk orienterede, og som har svært ved at sige nej: Generalerne.

Trump har efterhånden alle sine ministre på plads, og blandt dem findes visse erfarne politiske kræfter, skal det dog siges. Tre af dem har erfaring fra Kongressen og har igennem længere tid været på politisk linje med Trump. Det drejer sig om Jeff Sessions, tidligere senator og længe involveret i Trump-kampagnen, som nu er blevet justitsminister; Tom Price, som i Repræsentanternes Hus i Kongressen kæmpede hårdt imod Obamas sygesikring (Affordable Care Act, eller Obama Care), og som er blevet sundhedsminister; og Mike Pompeo, som i 2015 i Kongressen gik hårdt til Hilary Clinton i Benghazi-høringerne, er blevet chef for CIA (som er i anden række i kabinettet).

Dette var den lille kerne af progressive Trump-kræfter med politisk erfaring. Andre ministre har politisk erfaring som transportminister Elaine Chao og beskæftigelsesminister Alexander Costa - men de har ikke været Trump-figurer. I tillæg vil onde tunger, at Elaine Chao kun fik posten, fordi hendes mand,
Mitch McConnell, er leder af Senatets republikanske flertal.

Flere af de tunge ministre er succesfulde forretningsfolk, som Trump har trukket til Washington. Udenrigsminister Rex Tillerson er en af dem, finansminister Steven Mnuchin en anden, handelsminister Wilbur Ross en tredje. De er dygtige mennesker, men de kender ikke lovgivningsprocessen og det politiske spil, og deres magt vil i høj grad afhænge af, hvor tæt de står på præsidenten.

Rex Tillerson har indtil nu været notorisk usynlig som udenrigsminister, hvilket har affødt en del kritik. Den positive udlægning er, at Tillerson bruger tiden på at opbygge et tæet forhold til præsidenten, så han senere vil blive set som præsidentens foretrukne aktør i udenrigspolitiske forhold. Er det rigtigt, så handler Tillerson klogt, men spørgsmålet er så, hvorfor Trump ikke hurtigere og mere effektfuldt får sin udenrigsminister i sving.

Hertil kommer, at topledelsen i Tillersons Udenrigsministerium endnu ikke er udnævnt, endsige bekræftet af Senatet. Tillerson udpegede i februar Elliott Abrams til at blive sin næstkommanderende, sin højre hånd, men Trump nedlagde veto grundet Abrams' kritik af Trump i valgkampagnen. Det var en alvorlig miskommunikation mellem de to, og siden har sagen om ministeriets ledelse stået stille.

Kabinettet består også af nogle ministre, som vil kæmpe en kamp mod deres eget ministerium - og disse risikerer at blive kilde til en slags guerillakrig internt i den føderale administration, herunder 
med interesseorganisationerne knyttet til den. Det drejer sig dels om Rick Perry, som nu skal lede det Energiministerium, han tidligere ville nedlægge. Perry fremstår dog efterhånden ret pragmatisk, hvilket man dog ikke kan sige om to øvrige ideologer: Betsy DeVos, der som frimarkedsorienteret undervisningsminister vil komme til at kæmpe mod den etablerede sektor; og Scott Pruitt, som i årevis indædt har kæmpet imod den Miljøstyrelse, EPA, som han nu skal lede.

\section{Sikkerhedsholdet}

Endelig er der det militære sikkerhedshold under Trump: Forsvarsminister Jim Mattis; Homeland Security minister John Kelly; og sikkerhedsrådgiver H. R. McMaster. Alle tre generaler - Mattis og Kelly er pensionerede Marines; McMaster er fra Hæren og stadig i tjeneste.

Ingen af disse var tætte på Trump i valgkampagnen. Mattis og Kelly kender til det politiske spil i Kongressen qua deres optrædener i høringer som repræsentanter for Forsvarsministeriet, men de har ikke tidligere tjent som politisk udnævnte spillere i lovgivningsprocessen. Desuden har hverken Mattis eller Kelly faet udpeget en næstekommanderende og må bero sig på 'hold-overs' fra Obama administrationen.

H. R. McMaster trådte ind som sikkerhedsrådgiver i februar, efter at hans forgænger, også tidligere general, Michael Flynn havde løjet og mistet især vicepræsident Mike Pences tillid, men også præsident Trumps. Flynn var (og er) under stærk mistanke for at have haft tætte forbindelser til Rusland, og det kan undre, at Trump lod stå til i så lang tid, ikke mindst fordi tiden mellem valget i oktober og indsættelse i januar var lang nok til at få et så vigtigt hold som sikkerheds- holdet på plads. At Trump igen måtte vende sig til den uniformerede verden for at finde en erstatning er sigende. Det er også sigende, at en pensioneret admiral (Bob Harward) først takkede nej, før tjenestegørende McMaster - som nyder meget stor anseelse som en nytænkende general - sagde ja. Havde McMaster sagt nej, lå den fjerde stjerne ikke lige for.

Hermed kommer vi til guerillakrigen i Det Hvide Hus, som står mellem de hidsige nationalister som politisk rådgiver Steve Bannon og opkomlingen Stephen Miller (som tidligere arbejdede for Jeff Sessions, nuværende justitsminister) og så mainstream-republikaneren Reince Priebus, der er Trumps stabschef, og som under valgkampen styrede det republikanske parti neutralt mellem kandidaterne - hvilket Trump var taknemmelig for. Det er her i Det Hvide Hus, at vi finder kampen mellem passion og eftertænksomhed, og kampen ruller.

Det bemærkelsesværdige er, at Trump virker ude af stand til at skabe orden $\mathrm{i}$ dette kaos - ude af stand til at skabe retning. Priebus er gentagne gange blevet rapporteret 'så godt som fyret', men til gavn for eftertænksomheden hænger han fast endnu.

Sagen i Det Hvide Hus er, at for mange mennesker har adgang til præsidenten som er let at påvirke og derfor nogle gange peger i øst andre gange i vest. Så længe styringen i Det Hvide Hus sejler, vil præsidenten ikke kunne give retning til sine ministre. Og så længe Trump fortsætter sine outrerede tweets - som at beskylde Obama for lovbrud og kalde ham 'bad (or sick)' - vil han vedblive at skabe forvirring i toppen af sin administration og hele vejen ned.

De enkelte ministre kan selvsagt lede, men det bliver i hver deres retning. Om- 
verdenen vil således blive (yderligere) forvirret og kræve opklaring, og præsidenten vil finde yderligere anledning til at mene, at etablissementet er imod ham.

\section{Populisten Trump}

Trump blev som bekendt ikke valgt af etablissementet, men derimod takket være sin populistiske stil og appel. Umiddelbart virker Trump malplaceret. USA har en stærk multikulturel tradition, som i sig selv er et bolværk mod populisme. Til gengæld har Europa - grundet sammenblandingen af nation og stat og også det stærke aristokrati, som har præget europæisk historie - haft en lang tradition for populisme. De mest kendte diktatoriske modeller er fascisme, kommunisme, nazisme. I dag kommer populismen i nye klæder - nationale - men helt i tråd med populismens potentiale for diktatur appellerer de nye populister til 'folket' og fordømmer 'eliterne' i det repræsentative demokrati.

Trumps populistiske appeal er dog ikke 'made in Europe', men ganske hjemmegroet. Trumps profil og politiske appel rammer midt ned i klassiske amerikanske debatter om deres republik og politiske institutioner. I hvor høj grad skal demokratiet være indirekte? Hvordan skal repræsentative institutioner og folkelig deltagelse balanceres? Og hvor stærk skal præsidenten og præsidentembedet være?

Populistisk passion var ikke yndet blandt USA's grundlæggere, founding fathers, som skrev den amerikanske forfatning. De vægtlagde formelle begrænsninger og institutionelle balancer, som skulle fremme dialog og ræsonneret politik og beskytte det amerikanske demokrati mod passion og oprør. Det var en liberal vision for, hvordan en central (føderal) stat kunne opbygges og stadig være ansvarlig over for vælgerbefolkningen.

Denne tradition, denne liberale arv, har været udsat for kritik af folk, som ser den som elitær og en slags liberal aristokratisk model. Ifølge kritikerne gør de amerikanske politiske institutioner politik til en slags tilskuersport, hvor vælgerne bliver passive og uden tro på egen indflydelse. Resultatet er, igen ifølge kritikere, at det politiske system skaber populær frustration og vrede, alt sammen bundet i en følelse af at institutionerne ikke er til for folket men for eliten.
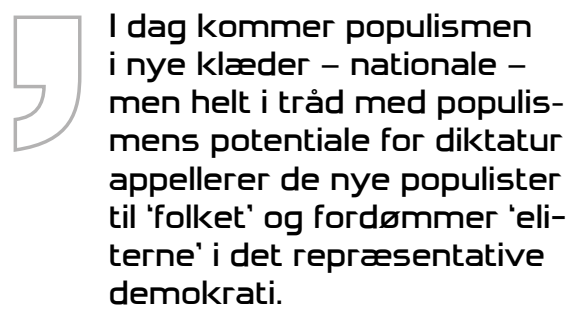

Som Walter Russell Mead og andre analytikere og observatører har noteret, så er Trump det seneste skud på stammen af amerikansk populisme. Trump er en ny udgave af det oprør, som Andrew Jackson stod for i det tidlige 19. århundrede, da han var præsident fra 1829 til 1837. I dag pryder Jackson i øvrigt 20 dollar-sedlerne. Jacksons præsidenttid blev et vendepunkt i amerikansk politisk udvikling på den måde, at det skabte en populær og aktivistisk præsidentrolle og altså en tradition for at skubbe balancen i forfatningens institutioner i retning af populistisk, udøvende magt.

Selvfølgelig er der forskelle mellem dengang og nu. Jackson vandt sit valg i 1828 stort (han vandt også i 1824, men tabte i sidste ende en afstemning i Repræsentanternes Hus); Trump vandt som bekendt kun et mindretal af de afgiv- 
ne stemmer, men et flertal af valgmandsstemmerne. Jackson voksede op under beskedne vilkår og var en militær helt fra krigen mod England i 1812; Trump er privilegeret og har ikke tjent i militæret.

Men lighederne er alligevel markante. De er begge fortalere for (den hvide) arbejderklasse og det tyndt befolkede 'rural America'; de går begge direkte imod gængs liberal politik på stort set alle områder; de er direkte i deres kritik af domstole samt regeringsbureaukratiet; og de peger på 'fremmede' som en trussel mod den amerikanske nation. For Jackson var det indianerne (som han bekrigede og forflyttede til 'Indian Territory'); for Trump er det muslimer.

Man skal efterhånden være godt naiv for at undervurdere Trumps evne til at forfølge denne Jackson-tradition i amerikansk politik. Trump har greb om de traditionelle arbejderklassebastioner, og han har nu kapret den republikanske græsrodsorganisation CPAC, som tidligere var stærkt kritisk over for ham. Hertil kommer, at al den larm, som han genererer med tweets og mærkværdige udtalelser, er et grundelement $i$ hans politiske kommunikation. Jo mere oprørt hans liberale opponenter bliver, jo stærkere får han profileret sit politiske projekt.

På den anden side skal man heller ikke falde for hans appel. I de første par måneder har han ført symbolpolitik - med indvandringsforbud og højesteretsudnævnelse blandt andet, men nu kommer det hårde lovgivningsarbejde, hvor Trump dels kommer til at skade den middelklasse, som har stemt ham ind, dels kun vil få sine projekter gennemført, hvis han forstår at samarbejde med Kongressen.

Når det gælder politisk samarbejde, er Trump en amatør, og selvom Republika- nerne har flertal, så har de mange politiske varianter, og i tillæg har Demokraterne mulighed især i Senatet for at blokere budgetreformer. Hvis ikke Trump kan dyrke midten i alt dette, så vil hans lovgivning lide skibbrud.

Hertil kommer middelklassen, som Trumps planer for at styrke forsvaret og sikkerhed vil presse markant på pengepungen. Trumps budgetforslag, som blev sendt til Kongressen midt i marts, skærer ned på stort set alt undtagen forsvaret og homeland security. Det står nu ifølge Congressional Budget Office klart, at Trump og Republikanernes oprør mod Obamas sygesikring (Affordable Care) over en årrække vil skubbe 24 millioner mennesker ud af sygesikring og medføre store skattelettelser for de økonomisk privilegerede. I tillæg er Trump endnu ikke kommet i gang med sine planer om skattelettelser for private og erhverv - igen politiske tiltag, der vil presse regeringens evne til at servicere den brede middelklasse, og som uomstrideligt vil gavne de privilegerede.

Trumps populistiske profil vil næppe kunne holde til summen af dette pres på hans kernevælgere. Måske vil han kunne sløre det med sin politiske kommunikation; måske vil han moderere sin kurs. Men faktum er, at hans populistiske vej til magten ikke vil tjene ham lige så godt, når nu han er inde $\mathrm{i}$ institutionerne $\mathrm{og}$ skal skabe politiske løsninger.

\section{Nordamerika}

Vi ser samme udfordring - manglende evne til at arbejde inden for i modsætning til i opposition til institutioner - $\mathrm{i}$ Nordamerika og altså i forholdet mellem USA og dets to naboer, Canada og Mexico. Som europæerne er disse lande rystet af Trumps slogans, 'Putting America First' 
og 'Make America Great Again'. Det er en kvalitativ ny stil, for hvor tidligere amerikanske præsidenter også har talt om amerikansk storhed men kun justeret kursen, vil Trump ændre på selve principperne for godt naboskab.

Der gik mindre end en uge efter Trumps indsættelse den 20. januar, før han beordrede føderal finansiering af opførelsen af en mur mod Mexico og nærmest i samme åndedrag erklærede, at han ville genforhandle NAFTA-frihandelsaftalen mellem USA, Mexico og Canada. Disse to ting - NAFTA og muren - hænger sammen, for Trump har set NAFTA-genforhandling som en løftestang for at få Mexico til at betale for muren, enten gennem direkte betalinger eller indførelsen af told på varer fra $\mathrm{Me}$ xico.

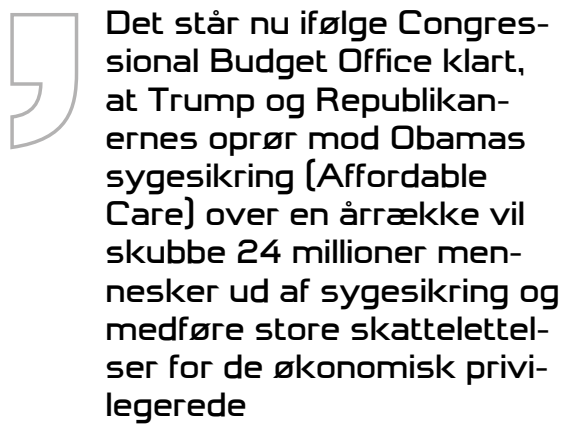

Men NAFTA handler om meget mere end muren, og kompleksiteten i traktaten vil givetvis overvælde Trump. Det ligger rimelig klart, at Trump vil sætte spørgsmålstegn ved en række grundelementer i traktaten. Det drejer sig om at skærpe kontrollen med de virksomheder, som eksporterer til USA, om at stramme reglerne for produkters oprindelse, inden de kan eksporteres til USA med NAFTA-præference, og om at svække mekanismen for at afgøre tvister omkring investeringer og særbehandling, den såkaldte Investor-State Dispute

Trump har noget kørende for sig, ikke mindst det faktum at ISDS-mekanismen er upopulær bredt i det amerikanske politiske miljø. Det gælder også Demokraterne, som traditionelt set er mere lunkne end Republikanerne, når det gælder frihandel. Men det gælder også Republikanerne, hvor mange er enige med Demokraterne i, at ISDS giver multinationale selskaber utilsigtet store privilegier i handelsspørgsmål.

Selv en traditionel frihandelstænketank som Cato Institute har meldt ud, at ISDS-mekanismen er en dårlig idé. Trump kan faktisk også finde opbakning i Europa, hvor ISDS-elementet af CETA-frihandelsaftalen med Canada var så omstridt, at det måtte erstattes med et mere politisk styret Investment Court System, ICS. Hvis det lykkes USA og EU at få TTIP-frihandelsaftalen forhandlet på plads - hvilket man kan tvivle på - vil den også bygge på ICS og ikke ISDS.

Tilbage i Amerika er det meget lidt sandsynligt, at Canada vil finde det besværet værd at udfordre Trump på ISDS, og Mexico kan ikke alene.

Men uanset hvor viljestærk Trump er $i$ at sætte en dagsorden for reform, så vil selve reformen kræve en lang og kompleks forhandling med kongressen.

Trump kunne unilateralt trække sig ud af TPP, fordi TPP ikke var ratificeret. Men det kan han ikke med NAFTA, som er ratificeret. Der kan han kun agere med Kongressens samtykke. Som alle moderne US-handelsaftaler, er NAFTA nemlig ikke en traktat, men en såkaldt 'congressional-executive agreement', som kun kan ændres i samarbejde mellem den udøvende og den lovgivende magt.

Med Trumps forhold til Kongressen 
vil dette sætte Trumps politiske kompromisevner og tålmodighed på prøve. Hans forhandlingspartnere, Mexico og Canada, vil vide, at tiden arbejder for dem. En langtrukken forhandling skaber usikkerhed omkring handel og investeringer og er dermed dårlig for amerikansk økonomi. Trump er under pres for at levere job, og i denne sammenhæng er det værd at bemærke, at den amerikanske centralbank ikke spiller Trumps spil, men hæver renten, fordi den vurderer, at opskruet vækst er uholdbar (vil overophede og skabe inflation).

Endelig vil Trump være under pres fra selve økonomien, som selvom den skaber vækst ikke nødvendigvis skaber arbejdspladser for Trumps kernevælgere af lavt uddannet arbejdskraft. Deres job forsvinder på grund af teknologisk rationalisering, som øger produktiviteten og skaber økonomisk vækst, men også behov for offentlig investering i arbejdsmarkedet $\mathrm{i}$ form af efteruddannelse til de arbejdere, der nu er blevet overflødige.

Men den slags offentlige investeringer er ikke en del af Trumps politiske udsyn. Trump har altså sat sig i en slags skruestik i forhold til hjemlige økonomi og naboerne, og det ser ikke bedre ud i den videre verden.

\section{Udenrigspolitik}

Vi ved egentlig meget lidt om Trumps udenrigspolitiske linjer. I slutningen af februar skrev tidligere sikkerhedsrådgiver Zbigniew Brzezinski med Paul Wasserman i New York Times meget sigende, at vi har brug for en 'Trump doktrin'. Ikke fordi Brzezinski er på Trumps hold, men fordi han efterlyser en rød tråd i en kaotisk-ledet administration.

På den ene side har Trump udfordret den bestående diplomatiske orden. Han har antydet, at Taiwan måske kunne anerkendes; at to-statsløsningen i konflikten mellem Israel og palæstinenserne måske ikke er en løsning; at NATO er en anakronisme; at Rusland er en partner; at EU er ligegyldig og kunne forsvinde; og at Iran skal konfronteres.

På den anden side har han korrigeret kurs på alle disse punkter, nogle gange ved egen hånd, nogle gange ved ikke at modsige sine ministre eksempelvis forsvarsminister Mattis og FN-ambassadør Nikki Haley, som henholdsvis har beroliget allierede og Israel og palæstinenserne. Der er altså et uforløst og usikkert potentiale for udenrigspolitisk revolution i Trump.

Én tendens er dog klar nok, og den er, at Trump gerne vil relatere sig til de store magter i det internationale samfund.

Det gælder Kina, som Trump har et dårligt øje til; og det gælder Rusland, som han har et godt øje til. I begge tilfælde vil dette direkte engagement vække stærk bekymring hos USA's allierede. I Asien vil Kinas naboer Japan, Sydkorea og Taiwan, som er allieret med USA, se med gru på, at USA-Kina forholdet varmer op til konflikt, fordi de ligger i skudlinjen.

Disse allierede har brug for stabilitet og langvaring inddæmning af Kina, som bygger på USA's vedvarende engagement i regionen. Trump har ikke bare udfordret stabiliteten; han har også sat spørgsmålstegn ved det langvarige engagement ved at trække USA ud af handelsaftalen Trans-PacificPartnership (TPP), som præsident Obama med besvær fik halet $i$ land.

Samme mønster ser vi i Europa. De varme følere til Rusland har kastet USA's allierede ud i en krise, igen fordi stormagtsrelationen vil gå ud over dem. Et 


\section{Vi skal forvente slinger i valsen. Den gode nyhed er, at slinger vil forstyrre og forhindre Trump i at søge store forandringer og altså vil være en slags aparte stabilitet.}

varmt forhold til Rusland kunne betyde, at Trumps USA vil forlade NATO - gå offshore - og koncentrere sig om andre dele af verden. De europæiske allierede vil naturligvis ikke gøre denne valgmulighed let for USA. De vil fremhæve de gevinster, de har ved at samarbejde det kunne være i Mellemøsten, i forhold til kampen mod terrorisme, eller økonomisk - og dermed spille på omkostningerne ved et brud, og de vil gøre det i fællesskab med de kræfter i USA, som har konkluderet, at Rusland manipulerede det amerikanske valg i 2016 og er en alvorlig trussel.

På sæt og vis er Trump i samme situation som Richard Nixon, som tiltrådte som præsident i 1969. Nixon var også en slags Jacksonian præsident, som ville udenrigspolitisk forandring (ikke mindst ud af Vietnam) og stormagtsdialog (hvilket 'abnede’ Kina). Nixon var ikke blind over for sine allieredes behov-fx ville han fokusere USA's militære magt i Europa - men han fik dem ikke rigtig med sig. Japan, Sydkorea og ikke mindst Taiwan var stærkt bekymrede for USA's nye kærlighed for deres regionale rival, Kina, og de europæiske allierede blev aldrig overbeviste om, at Nixons afspændingspolitik ville dem og ikke bare USA og Sovjetunionen det godt.

Det slående er, at Nixon og hans rådgiver Henry Kissinger - to uomstrideligt udenrigspolitiske begavelser - fandt denne øvelse svær. Når det gælder Trump, er udfordringen lige så stor, men begavelsen meget mindre.

Det er næsten helt givet, at Trump overvurderer sin mulighed for at skabe partnerskab med Rusland og undervurderer sine allieredes evne til at bremse hans planer. I Rusland må præsident Putin og hans rådgivere have svært ved at se holdbarheden i et partnerskab med Trump. Hvis de nærmer sig til ham, så er det ikke for at skabe en ny sikkerhedsarkitektur, men for at udnytte at Trump-vinduet står åbent.

De allierede kan i mellemtiden engagere de væsentlige dele af det amerikanske politiske miljø, der ser Rusland som en trussel. Det gælder store dele af Kongressen og også det amerikanske forsvar.

I Asien vil Kina helt givet spille på den lange bane. De har intet at vinde ved en krig med USA; de vil i stedet kanalisere politiske spændinger mellem USA og Kina ind i regional politik og puste til den nationalisme, som går imod USA. Filippinerne er et godt eksempel herpå.

Hvad enten det er i Europa eller Asien, har Trump brug for en velovervejet plan for, hvordan USA kan søge dialog med Rusland og Kina og samtidig holde vennerne tæt til sig - om ikke fordi han kan lide vennerne, så fordi vennerne i regionen er et grundelement, der fører Rusland og Kina til bordet.

En sådan plan er ikke i sigte. Vi skal forvente slinger i valsen. Den gode nyhed er, at slinger vil forstyrre og forhindre Trump i at søge store forandringer og altså vil være en slags aparte stabilitet. Den dårlige nyhed er, at vi må leve med, at det er svært forudsigeligt, hvad Trump vil gøre, den dag den store krise indfinder sig, og han skal træffe de vigtige beslutninger. 


\section{Trump får det svært}

Det er svært at skrive en konklusion om et 'moving target' som præsident Trump. Summen af ovenstående er dog, at han vil få det svært. Han mangler politisk erfaring og forbindelser, og hans temperament er i modsætning til det langsomme og tålmodige arbejde, som hjemlig lovgivning og internationale forhandlinger kræver. Trump er på sæt og vis en rendyrket populist, som strider mod institutioner og appellerer til folkets vrede og frustrationer. Han er stærk på symbolpolitik og politisk kommunikation men ikke til spillet i Washington og internationalt. Og selvom man er nok så meget imod det 'gamle' Washington - en 'sump som skal drænes' - så er landets føderale infrastruktur nu en gang sådan, at det er fra Washington, at lederskabet skal udgå.

\section{Trump passer fortrinligt på det, som Winston Church- ill engang sagde om USA: "a bull who carries his own chinashop with him".}

Vores konklusion er også, at Trump ikke skal afvises som en klovn, men indskrives og forstås som en populistisk reaktion på nogle centraliserende grundtræk i det amerikanske politiske system. Der er dele af USA, som ikke har det godt, og der er mange dele af USA, som synes, at Washington er fjernt og irrelevant. I et så stort land som USA er der bare afstand, og afstand skaber tilskuere til snarere end deltagere i den politiske proces.

Trump har fanget dette og på dygtig vis. På sigt kan man håbe, at Trump-effekten er, at de politiske institutioner bliver mere responsive over for de pressede amerikanere, som har stemt Trump ind i Det Hvide Hus.

Tilbage står så det faktum, at forandringen er fyldt med risici for ulykker. Trump passer fortrinligt på det, som Winston Churchill engang sagde om USA: "a bull who carries his own chinashop with him"-en tyr som bærer rundt på sin egen glasbutik.

Trumps de facto elitære økonomiske politik kan let skabe yderligere vrede, yderligere populisme. Fremtiden er en delikat balance. Men vores vurdering er trods alt, at institutionerne er stærkere end Trump, som vil blive slidt. Han vil derfor sandsynligvis ende med at gøre det, han er god til - føre kampagne. Han vil tematisere, provokere og symbolisere for at sole sig i sine tilhængeres begejstring.

Mon ikke om små fire år at Trump vil trække sig tilbage til Mar-a-Lago i Florida og overlade det til vicepræsident Mike Pence at føre revolutionen videre?

000 